\title{
ANALISIS PENGARUH MACROBENDING PADA SENSOR ALBUMIN URIN DENGAN METODE EVANESCENT MENGGUNAKAN SERAT OPTIK FD 620-10
}

\author{
Haryanto Saputra*, Harmadi Harmadi, Afdhal Muttaqin \\ Jurusan Fisika FMIPA Universitas Andalas, Padang \\ Kampus Unand Limau Manis, Pauh Padang 25163 \\ *Korespondensi ke: hary.putra.aje@gmail.com
}

( Diterima:21 Januari 2019; Direvisi: 9 Februari 2019; Diterbitkan: 01 Maret 2019)

\begin{abstract}
ABSTRAK
Telah dilakukan analisis pengaruh macrobending pada sensor albumin urin dengan metode evanescent menggunakan serat optik FD 620-10. Sumber cahaya dari laser dioda dengan panjang gelombang $650 \mathrm{~nm}$ ditransmisikan pada serat optik multimode. Pengupasan cladding serat optik sepanjang $3 \mathrm{~cm}$ mengakibatkan pelemahan intensitas terukur pada detektor akibat interaksi gelombang evanescent dengan molekul albumin dalam urine. Sensor albumin urin dikarakterisasi berdasarkan tegangan keluaran fotodioda. Hasil karakterisasi sensor menunjukkan serat optik pada jari-jari bending 2,5 $\mathrm{cm}$ adalah yang optimal untuk pengukuran kadar albumin urin dengan sensitivitas sensor sebesar $0.001(\mathrm{mg} / \mathrm{dL}) / \mathrm{V}$. Tegangan keluaran fotodioda semakin mengecil seiring meningkatnya kadar albumin urin.

Kata kunci : macrobending, serat optik, albumin urin.
\end{abstract}

\section{ABSTRACT}

An analysis of macrobending influences on urinary albumin sensors using the evanescent method using FD 620-10 optical fiber has been analyzed. The light source of a diode laser with a wavelength of $650 \mathrm{~nm}$ is transmitted on multimode optical fibers. Stripping the $3 \mathrm{~cm}$ optical fiber cladding resulted in the attenuation of the measured intensity at the detector due to the interaction of evanescent waves with albumin molecules in the urine. Urine albumin sensor is characterized based on the photodiode output voltage. The results of sensor characterization show that optical fibers in bending radius of $2.5 \mathrm{~cm}$ are optimal for measuring urine albumin levels with sensor sensitivity of $0.001(\mathrm{mg} / \mathrm{dL}) / \mathrm{V}$. The photodiode output voltage decreases with increasing urine albumin levels..

Keywords: macrobending, optical fiber, urine albumin. 


\section{PENDAHULUAN}

Indonesia merupakan negara dengan tingkat penderita gagal ginjal yang cukup tinggi. Menurut hasil survei yang dilakukan oleh Perhimpunan Nefrologi Indonesia (Pernefri) diperkirakan ada sekitar 12,5\% dari populasi atau sebesar 25 juta penduduk Indonesia mengalami gagal ginjal (Putri dkk., 2016). Gagal ginjal adalah suatu penyakit dimana fungsi organ ginjal mengalami penurunan sehingga urin ditandai dengan adanya albumin (Rahayu, 2013). Albumin adalah protein plasma darah utama dan biasanya disaring kembali oleh ginjal di filtrasi glomerulus. Probabilitas tinggi kerusakan kapasitas filtrasi glomerulus ginjal adalah ketika kadar albumin terukur sekitar 30-300 mg/hari (Sack dkk., 2002). Pemeriksaan khusus guna mencegah dampak terburuk yang ditimbulkan oleh albumin yang lolos ke urin perlu dilakukan. Pemeriksaan ini dapat direalisasikan dengan melakukan pengembangan sistem pengukuran kadar albumin urin dalam penelitian.

Beberapa penelitian telah dilakukan untuk mengembangkan sistem pengukuran kadar albumin. Park dkk. (2008) menggunakan sensor Biofield Effect Transistor (BioFET). Hasil pengukuran menunjukkan sinyal tegangan keluaran cukup linier dengan sampel yang mengandung konsentrasi albumin antara $30 \mathrm{mg} / \mathrm{L}$ sampai $100 \mathrm{mg} / \mathrm{L}$. Karakterisasi sensor BioFET yang bergantung dengan menggunakan SEM membuat perancangan alat tidak ekonimis. Cmiel dkk. (2016) melakukan pengukuran albumin berbasis optik yang menggunakan ponsel iPhone dan miniatur adaptor optik sebagai sistem alat. Pengukuran tersebut memanfaatkan kamera untuk mengukur tingkat cahaya yang dipancarkan. Sistem pengukuran ini menunjukkan kurva dengan tingkat linieritas yang cukup tinggi yaitu $\mathrm{R}^{2}=$ 0,998. Kelemahan yang ditemukan yaitu batas deteksi tidak begitu tepat karena tidak ada penghubung tertentu antara sumber cahaya dengan kamera iPhone sehingga pancaran cahaya tidak maksimal ditangkap oleh kamera iPhone.

Serat optik sekarang ini banyak digunakan sebagai sensor. Serat optik memiliki kelebihan diantaranya respon pengukuran yang sangat cepat, presisi dan akurasi yang tinggi, serta adanya penghubung antara sumber cahaya dengan fotodetektor (Zulaichah, 2004; Fidanboylu dan Efendioglu, 2009).

Serat optik adalah media transmisi gelombang cahaya yang terbuat dari silika atau plastik berbentuk silinder (Crisp dan Elliott, 2008). Sensor serat optik evanescent dapat dilihat seperti Gambar 1.

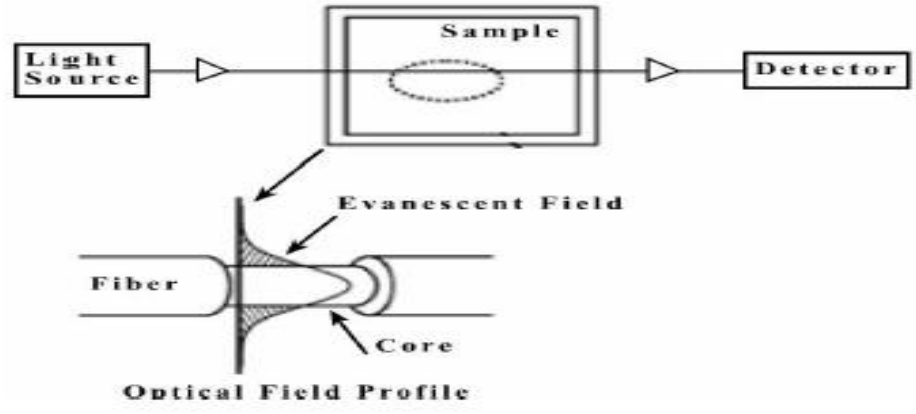

Gambar 1. Sensor serat optik evanescent

(Sumber: Fidanboylu dan Efendioglu, 2009)

Proses penjalaran cahaya didasarkan pada perubahan spektra absorpsi gelombang evanescent pada batas antara inti dan cladding serat optik. Sensor evanescent bekerja 
didasarkan pada prinsip efek gelombang evanescent. Nilai yang berpengaruh dalam gelombang evanescent adalah perubahan nilai indeks bias cladding. Perubahan nilai indeks bias cladding akan menentukan kedalam penetrasi $\left(d_{p}\right)$ gelombang evanescent. Gelombang cahaya yang memasuki cladding sepanjang $d_{p}$ akan berkurang secara eksponensial. Semakin dalam penetrasi gelombang evanescent, semakin kecil intensitas cahaya yang terpandu melalui serat optik.

Pada penelitian ini telah dikembangkan dan dianalisis sensor albumin urin dengan memanfaatkan pelemahan cahaya akibat interaksi gelombang evanescent dengan molekul albumin di dalam urin. Tegangan keluaran fotodioda berkurang seiring meningkatnya kadar albumi urin. Sampel yang digunakan adalah urin penderita gagal ginjal yang dilarutkan dengan asam asetat $6 \%$.

\section{METODE PENELITIAN}

\subsection{Perancangan Sistem Diagram Blok}

Sistem pengukuran kadar albumin ini menggunakan sistem sensor serat optik dengan metode evanescent. Serat optik melakukan penginderaan dengan cara memodifikasi cladding serat optik FD 620-10 multimode. Modifikasi dilakukan dengan cara mengupas coating serat optik dengan cutter sepanjang $3 \mathrm{~cm}$. Cladding asli yang berupa selaput, dikupas dengan cara mengikis permukaan serat optik atau melepaskannya secara perlahan sehingga nantinya sampel urin menjadi cladding-nya. Selanjutnya, sensor serat optik dikarakterisasi dengan variasi jari-jari bending $2,5 \mathrm{~cm}, 3,5 \mathrm{~cm}$, dan $4,5 \mathrm{~cm}$ untuk melihat pengaruh bending pada sensor albumin urin. Hasil proses mikrokontroler ditampilkan pada layar LCD. Secara umum diagram blok sistem secara keseluruhan dapat diperhatikan pada Gambar 2.

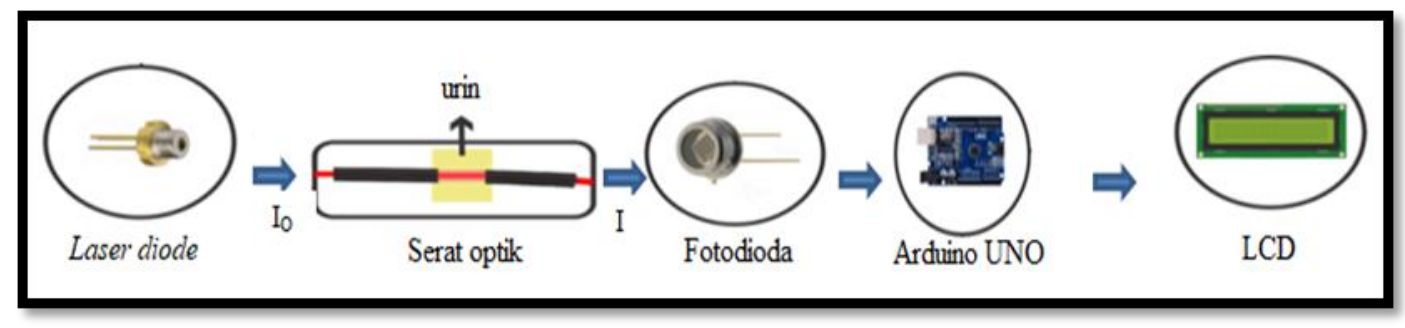

Gambar 2. Diagram blok sistem pengukuran kadar albumin urin

\subsection{Diagram Alir Perangkat Lunak Sistem}

Sistem instrumentasi yang berbasis mikrokontroler memerlukan urutan instruksi yang disebut program. Program sistem alat ukur kadar albumin ini ditulis dalam bahasa pemrograman IDE arduino. Perancangan perangkat lunak dari alat ukur kadar albumin ini dimulai dari perancangan diagram alir. Perancangan perangkat lunak sesuai dengan prinsip kerja dari sistem yang dibangun. Persamaan regresi yang dimasukkan ke dalam program diperoleh dari grafik hasil karakterisasi alat ukur yaitu hasil kadar albumin laboratorium $(\mathrm{mg} / \mathrm{dL})$ terhadap hasil pembacaan ADC mikrokontroler. Berdasarkan prinsip kerja sistem yang direncanakan maka diagram alir program dapat ditampilkan seperti Pada Gambar 3. 


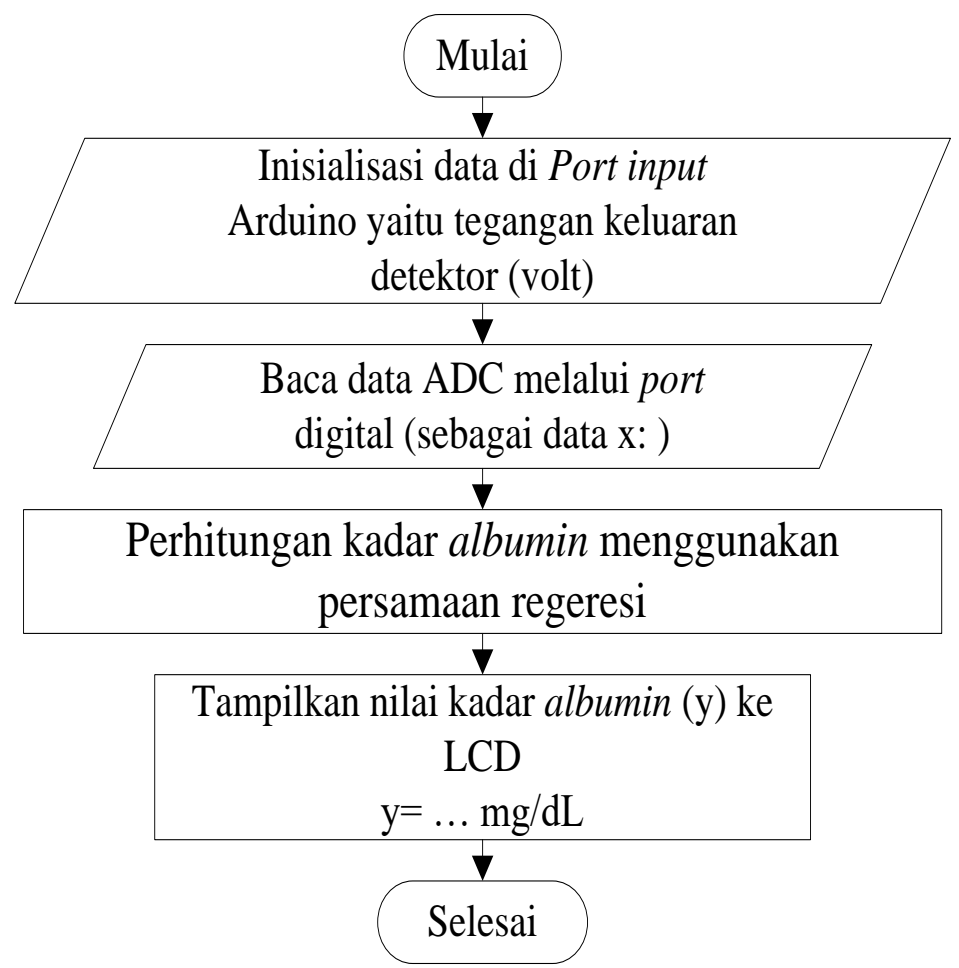

Gambar 3. Diagram alir program

\subsection{Perancangan Sistem Pengukuran Kadar Albumin Urin}

Perancangan sistem sensor serat optik memerlukan serat optik sepanjang $21 \mathrm{~cm}$. Sistem terdiri dari PC, alat ukur kadar albumin urin, fotodetektor, laser diode, serat optik dan tempat sampel. Spesimen uji dari perancangan alat ukur albumin ini dibuat dengan mereaksikan 3 sampel urin penderita gagal ginjal yang memiliki tingkat albumin pereduksi berbeda-beda dengan larutan asam asetat $6 \%$. Tingkat kadar albumin urin pada penelitian ini adalah $15 \mathrm{mg} / \mathrm{dL}, 30 \mathrm{mg} / \mathrm{dL}$ dan $100 \mathrm{mg} / \mathrm{dL}$. Gambaran sistem pengukuran kadar albumin urin dapat dilihat pada Gambar 4.

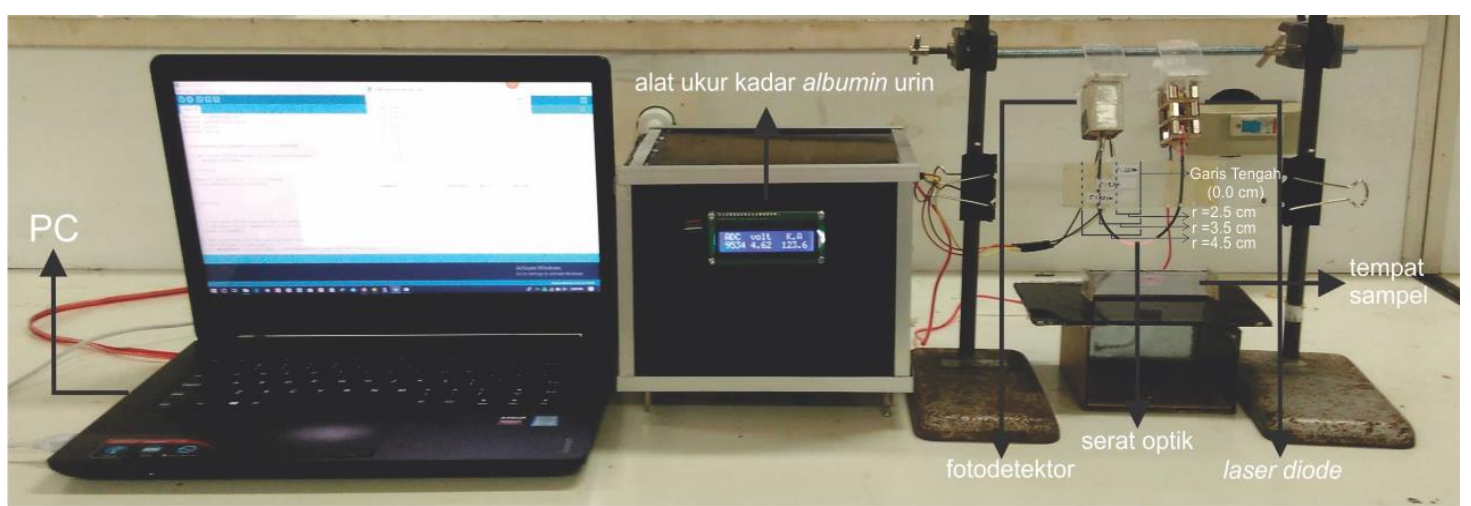

Gambar 4. Gambaran sistem pengukuran kadar albumin urin 


\section{HASIL DAN DISKUSI}

\subsection{Karakterisasi Sensor Serat Optik}

Karakterisasi sensor serat optik dilakukan dengan melihat hubungan antara tegangan keluaran sensor dengan kadar albumin dalam sampel urin. Plot data hasil karakterisasi dengan variasi jari-jari bending ditampilkan pada Gambar 5.

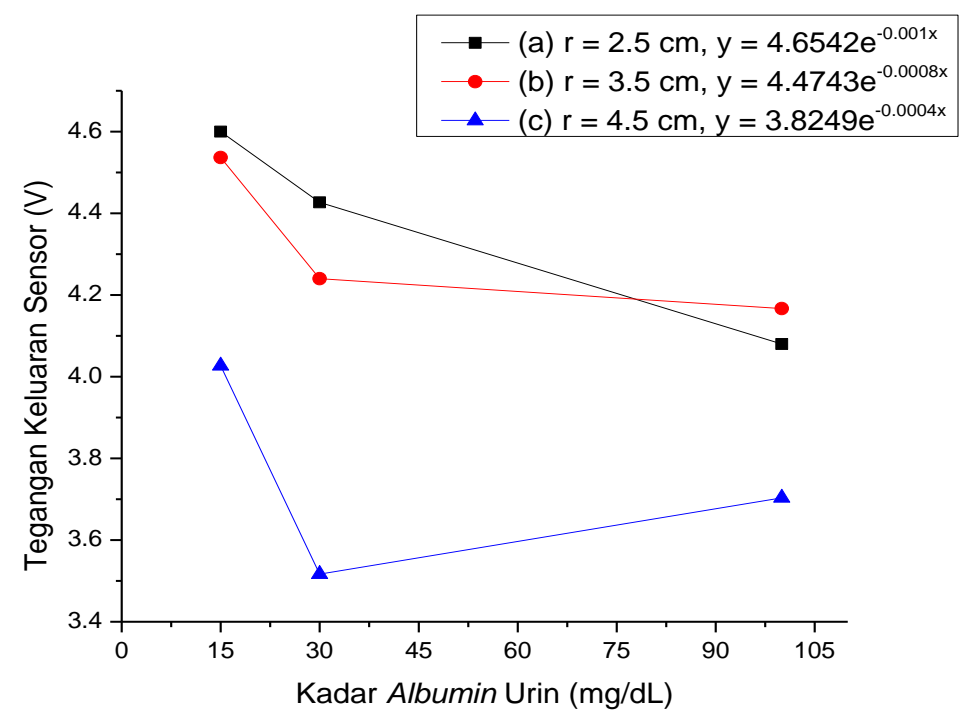

Gambar 5. Grafik hubungan tegangan keluaran sensor terhadap kadar albumin urin dengan variasi jari-jari bending (a) $2,5 \mathrm{~cm}$, (b) $3,5 \mathrm{~cm}$, dan (c) $4,5 \mathrm{~cm}$

Semakin kecil jari-jari bending maka tegangan keluaran akan semakin tinggi akibat pelemahan gelombang evenescent karena cahaya yang diterima fotodetektor semakin kecil. Kecenderungan (trend) tegangan keluaran sensor dan kadar albumin urin menunjukkan sensitivitas dan persamaan curva fitting.

\subsection{Data Hasil Karakterisasi Sensor}

Data hasil analisis dapat dilihat pada Tabel 1.

Tabel 1. Data hasil analisis karakterisasi sensor

\begin{tabular}{ccc}
\hline No. & $\begin{array}{c}\text { Jari-jari Bending } \\
(\mathrm{cm})\end{array}$ & $\begin{array}{c}\text { Sensitivitas Sensor } \\
((\mathrm{mg} / \mathrm{dL}) / \mathrm{V})\end{array}$ \\
\hline 1 & 2.5 & 0.001 \\
2 & 3.5 & 0.0008 \\
3 & 4.5 & 0.0004 \\
\hline
\end{tabular}


Hasil karakterisasi sensor serat optik menunjukkan bahwa pengukuran kadar albumin urin yang optimal yaitu pada jari-jari bending $2.5 \mathrm{~cm}$ dengan nilai sensitivitas sensor tertinggi yang diperoleh berdasarkan hasil analisis pada Tabel 1 sebesar 0.001. Hal ini terjadi karena semakin tinggi kadar albumin urin, semakin rendah tegangan keluaran akibat atenuasi cahaya yang berinteraksi dengan molekul albumin urin. Penyerapan dan hamburan gelombang evanescent yang terjadi berbanding lurus dengan kadar albumin urin dan berbanding terbalik secara eksponensial dengan tegangan keluaran sensor yang didapatkan.

\section{KESIMPULAN}

Pengaruh macrobending pada sensor albumin urin dengan metode evanescent memperlihatkan perubahan tegangan keluaran dan nilai sensitivitas sensor. Nilai sensitivitas sensor tertinggi pada jari-jari bending $2,5 \mathrm{~cm}$. Semakin kecil jari-jari bending maka intensitas cahaya semakin berkurang diterima oleh detektor, sehingga tegangan keluaran sensor juga semakin menurun seiring meningkatnya kadar albumin urin.

\section{UCAPAN TERIMAKASIH}

Penulis mengucapkan terima kasih banyak kepada bapak Dr. Harmadi dan bapak Afdhal Muttaqin, M.Si selaku pembimbing dalam penelitian ini dan selurus pihak yang telah turut membantu dalam penyelesaian penelitian ini, serta pihak rumah sakit Dr. Reksodiwiryo yang telah mengizinkan penulis memperoleh sampel urin untuk penelitian ini.

\section{DAFTAR PUSTAKA}

1. Cmiel V., Svobodaa O., Koscovaa P., Provaznik I., 2016, Smart-phone based pointof-care Detector of Urine Albumin, Vol. 9715 971508-1, SPIE, hal. 1-9.

2. Crisp, John dan Elliott, Barry. 2008. Serat Optik. Edisi ke-3. Erlangga. Jakarta.

3. Fidanboylu, K. dan Efendioglu, H.S., 2009, Fiber Optic Sensors and Their Aplications, 5th International Advanced Technologies Symposium, 13-15 Mei 2009.

4. Frederick, A., 1990, Fiber Optics Hand Book for Engineers and Scientist, Mc GrawHill, United States.

5. Park K.Y, Sohnb Y.S, Kimc C.K, Kimd H.S, Baee Y.S, Choia S.Y, 2008, Development of FET-type albumin sensor for diagnosing nephritis, Elsevier, hal. 702-701

6. Putri T. D., Mongan A.E., Memah M.F., 2016, Gambaran kadar albumin serum pada pasien penyakit ginjal kronik stadium 5 non dialisis ,Vol. 4, No. 1, e-Biomedik, hal. 173-177

7. Rahayu S., 2013, Sistem Pakar Untuk Mendiagnosa Penyakit Gagal Ginjal Dengan Menggunakan Metode Bayes, Vol. 4, No. 3, ISSN, hal. 2301- 9425

8. Sacks D.B., Bruns D.E., Goldstein D.E., Maclaren N.K., McDonald J.M., Parrott M., 2002, Guidelines and recommendations for laboratory analysis in the diagnosis and management of diabetes mellitus, Vol. 48, No. 3, Clin Chem, hal 436-472.

9. Zulaichah, S., 2004, Pengukuran Frekuensi Getaran Menggunakan Serat Optik, Skripsi, ITB, Bandung. 